\title{
Moving from Legislation to Implementation: Participants' Resolve on Inheritance Property of Women
}

* Shahla Tabassum, PhD Scholar (Corresponding Author)

** Dr. Amber Ferdoos, Assistant Professor

\begin{abstract}
This paper attempts to develop a mechanism to overcome inequality present in the context of inheritance property of women in Pakistan. Taking a feminist research stand that focused on knowledge construction as a way to suggest alternatives for changes in oppressive situations. Data collected from thirty men, women of rural, urban settings, and ten male and female lawyers from the Pothohar region through self-exploratory semi-structured qualitative interviews. The findings revealed procedural changes at the state level such as the offices where property transfer happened as well as recommended to set up a monitoring cell to see the record of the court decisions about inheritance property of women. Moreover, the findings highlighted community-level changes to spread awareness through various means like media, social media, Friday sermons, and seminars at union council levels about the inheritance property of women. Furthermore, findings also indicated changes at the family level as a combination of state decisions to make a change in the family headship, changing mindset through awareness as well as the training of boys and girls on equal footing at home.
\end{abstract}

Keywords: Inheritance, Women, Legislation, Implementation, Solutions

Introduction

The paper focuses on strategies to reduce inheritance property inequality in the context of Pakistani women. Inheritance property is anything immovable (land, housing, etc.) or movable (jewelry, money, etc.) received from ancestors under the law and the person who receives property from ancestors or parents is called the heir (Black's Law Dictionary, 1999). There is a huge gender disparity present in terms of inheritance property at the global and local levels. A large number of researches have been done internationally and nationally to understand women's situation concerning inheritance property (Harari, 2014; Grabe, Dutt \& Dworkin, 2014; Deininger, Goyal \& Nagarjan, 2013; Luke \& Munchi, 2011; Qian, 2008; Duffo, 2003; Quisumbing \& Otsuka, 2001).

The majority of researches in Pakistan conducted on cultural and legal impediments and concluded that as a result of these obstacles, women withdraw from their inheritance property. A recent study conducted in the Pakhtun cultural context showed a significant association between the denial of inheritance and cultural obstacles (Bibi \& Bangash, 2018). The Government of Pakistan has made legal reforms to provide women their share of inheritance property but the situation is still grim. There are only a few women who are entitled to land ownership and it is less than 3\% in Pakistan (HRCP, 2008) and in Punjab, it is almost 10\% (Shafqit \& Zahir, 2016).

\section{Literature Review}

Gender inequality in property ownership is globally recognized and the Food and Agriculture Organization (FAO) (2016) highlighted in its report the relationship between poverty reduction and land ownership. International scholars indicated in their researches, land rights for women as a key indicator of economic empowerment (Kenny \& Ana, 2016; Domingo, 2013; Kelker \& Maithreyi, 2013; UNESCAP, 2013; UNDP, 1995). One way of protecting their land rights and empowering women is to ensure their inheritance rights (Kelker \& Maithreyi, 2013; GENDERNET, 2012; Rao, 2005; Strickland, 2004; Agarwal, 1996a).

A large number of studies in Pakistan have been conducted to see the challenges that women are facing to get their inheritance share. Rubab, Parveen, and Usman (2016) in their study highlighted strict legal procedures, high level of education, legal awareness, and changing patriarchal mindset as determining factors for women to get their inheritance share. Holden and Chaudhary (2013) in their

* Department of Sociology, International Islamic University, Islamabad Email: shahlatabassum@ fjwu.edu.pk ** Department of Sociology, International Islamic University, Islamabad Email: amber.ferdoos@iiu.edu.pk 
study argued that everyday practices of law in Pakistan are so complex and complicated and have powerful implications on women that they prefer not to go through with the court.

Moreover, studies also focused on the effects of legal implications, lack of awareness, and patriarchal nature of the legal system on women (Ahmad, 2010; Rehman, 2010. NCSW, 2008; SDPI, 2008; Mehadi, 2002). Studies also highlighted cultural factors like considering women as property and still use them to solve cases of disputes within the families along with legal practices that create difficulty for women to get benefits from their legal and religious right of inheritance (Judoon \& Khan; 2015; Zaman, 2014; USAID, 2013).

Inheritance distribution in Pakistan is regulated according to Islamic shares under section 2 of the "Shariat Application Act, 1962". There is no distinction in the Islamic distribution of inheritance share related to movable and immovable property. But the matters related transfer of inheritance share falls under different laws such as movable inheritance property matters deals under "Succession Act, 1925 " as well as urban inheritance property matters that come under "Relief Act, 1877" and these fall in the jurisdiction of civil courts. An Heirship certificate has to obtain from the civil courts and courts only confirm the names of those who inherit property. If any dispute arises, then it is settled in court. Agriculture inheritance property is transferred under the "Land Revenue Act, 1967".

Several legal reforms were made in Pakistan to make it convenient for women to get their due share from inheritance. The "Transfer of Property Act, 1882" sub-section 6(1) was amended in favor of women about non-withdrawal of their inheritance share. Also, the "Stamp Act, 1889" section 9(a) was amended to exempt stamp duty in agricultural land if it is gifted to a legal heir. Furthermore, in the context of agricultural land, another amendment in section 78 of the "Registration Act, 1908" was made by exempting payment of registration fee while making a portion of the land deed.

Amendments were also made in procedures of mutation in section 42 of the "Land Revenue Act, 1967" to make the procedure easy. In "Punjab Land Revenue Act, 1967", an amendment in section 135-A was made for joint holders for land portion after inheritance mutation without any application within thirty days. As well as "Enactment of Punjab Partitioning of Immovable Act, 2012" exempted women from registration fees on documents and the only token fee of Rs. 500/- can be submitted in case of suffering as a joint owner in inheritance agriculture land. Another amendment was made under "Punjab Revenue Rules, 1968" about the duties of Revenue Officer in attestation of inheritance mutation. One more amendment was made in "Punjab Pension Rules, 2009" added a share to divorced daughter and unmarried sister of a deceased government employee in pension till life after a widow, infant and unmarried daughter.

Few other amendments were made in 498-A and 498-C of Pakistan Panel Code (PPC) protect women inheritance under the "Prevention of Anti-Women Practices Act, 2011" with a maximum imprisonment of ten years and not less than five years and 498-C under Prohibition of Marriage with the Holy Quran with a maximum imprisonment of seven years and not less than three years. In the presence of all these amendments, still women are unable to get their inheritance share and that requires the government to move from legislation to a comprehensive implementation plan that helps women in getting their inheritance property.

\section{Theoretical Framework}

The knowledge constructed in this study is based on feminist perspectives, taken from three feminists who challenged positivist epistemology and argued that all human knowledge is a product of social experience, as well as argued that the production of knowledge is politically engaged activity (Stanley $\&$ Wise, 1993). The purpose of all feminist knowledge production is to understand women's view of the world and emancipate women during the research process (Harding, 1987). Feminist research not only addresses the question of women's oppression, inequalities, and exploitation but also suggests strategies to overcome these inequalities and exploitations (Abbott, Wallace, \& Tyler, 2005). This paper suggests strategies to overcome the denial of inheritance rights of women in Pakistan. As a believer in feminist epistemology and the whole research process from developing a research question to strategies hold a feminist perspective. By raising question on power relation embedded in the family and gender division of work in this study as these are the main obstacles in denying inheritance rights of women in the family and these are consistent with two of the assumptions of Thorne (1987) who argued four assumptions of the conventional family ideology that feminist have challenged includes division of labor, family as a category of analysis, power relation in the family and family as a private sphere. 


\section{Research Methodology}

The objective of the research paper is to develop a mechanism of implementation to improve the prevailing situation of women concerning their inheritance property in Pakistan. It is qualitative research with a feminist epistemology that also emphasis to suggest changes to alter the existing reality. Forty men, women of rural and urban areas as well as male and female lawyers from Rawalpindi and Chakwal region participated with selection criteria to take part in the study. SemiStructured Exploratory Interviews were done to get information from the experiences of men and women regarding the inheritance property of women. This research method was used because of the sensitive nature of the issue within the communities and the hesitation of participants to meet again because of their property conflict within the families. An interview guide consisted of four parts background, law-related, opinion, and experienced-based questions were developed. The data collection took six months as one interview took two to three times to schedule for one meeting with their place of concern.

Data were analyzed by using Bran and Clarke's (2006) six steps thematic analysis for developing themes. Initially, all the audio-recorded interviews were transcribed, and then, codes were assigned while familiarizing with the data. In the third step, all these codes were organized into different conceptual categories. Forth step included analysis of all the categories through a feminist lens developed for this study. In the fifth step, these theoretical categories are labeled under different themes. In the final and last step, these themes were reported in the result section. In qualitative research, objectivity and truthfulness of the research is an important aspect, and to maintain it, Guba and Lincoln (1994) criteria were used to evaluate the objectivity of the research findings that included creditability, transferability, dependability, and conformability.

The entire research process was carried out by keeping all ethical considerations and a willingness was obtained by the participants. The purpose was conveyed to them and permission was taken to record the interviews. They were asked to leave the interview when and where they feel uneasy. The interviews were conducted by the first researcher herself and the place was selected at the convenience of participants. The confidentiality of participants was maintained by using numbers instead of names during the data analysis and reporting period.

\section{Results and Discussion}

The findings focused on the changes required from the state, community, and family levels about the implementation of the existing laws of transfer of inheritance. As most of the participants (Urban Female 2, 4; Rural Female 2, 3; Male Lawyer 1, 3,4,5; Female Lawyer 1, 2) recommended strict implementations to provide women their inheritance share. A four-tier mechanism is developed for implementing the legal reforms made in Punjab under the following themes:

\section{Procedural Changes: Measures at State Level}

Inheritance is distributed according to stated legal and religious shares and rules of inheritance shares are used to make decisions on inheritance disputed cases in the Pakistani courts accordingly. There is no monitoring system present to see whether women are getting their legal and religious shares. As Urban Female 3 said that Implementation of these laws should be made that held responsible all those brothers or fathers, who do not give women their share in the inheritance.

It is recommended by the participants that the government should establish a cell to monitor and record whether women are getting their legal and religious inheritance share.

"Unless there are changes in procedures of law and strict monitoring, women cannot have their due share". (Male Lawyer 5, Exploratory Semi-Structured Interview)

The results highlighted the inheritance share of a widow and it should not link with her remarriage but Pakistani society forced widows to withdraw their inheritance share if interested to remarry. Urban Male 2 narrated that a widow who lives with her brothers and they do not give her natal inheritance share because she is living with them. Another Urban Male 5 explained the situation of a widow in this way that a widow whose natal family forced her to remarry faced more pressure to withdraw her share from her brothers' in-laws. However, the participant's resolve regarding reducing the vulnerability of the widows was to monitor the practice of withdrawing widow share for getting remarriage.

Politically, it is structured on state apparatuses where all public offices related to transfer of property are maintained through masculine ideologies and women are not able to tackle these matters 
publically was discussed by Okin (1989) that division of labor within gender structure family creates multiple obstacles for women that handicap women in public life.

The findings also highlighted the lengthy and difficult documentation in the public office related to the transfer of inheritance property that is challenging to understand for women and handling the property matters independently. The participants also mentioned the difficulty to understand the language and they recommend making these documents in easy language. These results are consistent with the previous studies conducted in Pakistan (Holden \& Chaudhary, 2013; Judoon \& Khan, 2015).

The results reported participant's suggestions that recommend simplifying these documents and to make them people-friendly so people especially women can get advantages from the changes made by the government.

"It should be available in an easy language which is understandable for people". (Urban Male

$5 \&$ Male Lawyer 3, Exploratory Semi-Structured Interviews)

The findings also referred to the participants' further suggestion to include inheritance in the educational curriculum for future generations to familiarize them with the inheritance related terms used in landed property.

Furthermore, the findings of the study highlighted those women who initiate the legal procedure for getting their rights further go through torture in terms of delay in decisions from the courts. One of the participants mentioned a reason for the delay was the shortage of judges in the courts, which takes extra time, hiring more judges can solve the problem. (Male Lawyer 5, Exploratory Semi-Structured Interview). The findings highlighted the participant's suggestions as:

"Courts should take less time and not extend thirty years to give their decisions in property cases". (Rural Male 4, Exploratory Semi-Structured Interview)

"There must be a time limit for making decisions of property cases and should be fixed in five to six months". (Male Lawyer 1)

The findings also highlighted corruption and bribery as a norm in revenue offices for transferring the property which women never used to handle these matters. Urban Male 7 said that corruption is common in the legal system so difficult for women to get justice in this system. The participants suggested taking action to eliminate this practice in the legal system as this is one of the hurdles for women to take their rights.

"Strong system of justice is needed to stop corruption". (Rural Male 2, Exploratory SemiStructured Interview)

"The people who take bribes in inheritance matters should be prisoned". (Male Lawyer 5, Exploratory Semi-Structured Interview)

In the same manner, findings revealed the high charges of lawyers which is difficult for women to pay as they are financially dependent on men in the family. The participants also suggested making a list of lawyers who can provide women with legal assistance free of cost.

"There should be some concession in fees of lawyers if women are fighting for their inheritance rights". (Urban Female 1, Exploratory Semi-Structured Interview)

Denying inheritance of women within the family is political and the power dynamics present in the family due to the political decision of the state, assigned men as head of the family has power implications on women and this is seen through the different narrative of participants and these are aligned with feminist thoughts of second-wave feminism that personal is political in the broader context of power relations (Hanisch, 1969). Rural Male 2 stated that after the death of the father, the eldest son is the owner of the inheritance. The findings indicated that decisions of marriages are taken by the head of the family and how they bargain property is another narrative of the Urban Male 1 who shared his views like that the responsibility of parents is over when they married their daughters and they did not need to give their property to their daughters who are already going to someone else's house. Moreover, Urban Female 6 pointed out the reality as most of the time marriages consciously arranged because of keeping the property within men of the natal family. These are consistent with the previous researches in Pakistan as well (Mehadi, 2002; Rehman, 2010; NCSW, 2008; SDPI, 2008).

The findings revealed some suggestions to assign both men and women as head of the family instead of giving men the sole right of the head of the family. This will help women in absence of men and act as an opportunity to reduce their vulnerability and develop their agency to act independently so to make decisions in the family. The findings further highlighted that public places like 
government offices and courts are men specific which creates a stigma for women while going to these offices. The participants suggested appointing more women in public offices as well as, training men about handling women with respect.

\section{Emphasis on Awareness: Measures at the Community Level}

Blumberg (2004) highlighted inequalities based on power which is not only economic but also political and ideological. These cultural and ideological definitions of masculinity and femininity are basic parts of the system of gender inequality which started from the family. Inheritance is completed in two parts, first part indicates the share of the inheritance that is distributed in the family and the second part handles the transfer of the inheritance share and done in the public sphere. The first part is easy to understand but the second part is complicated and difficult to handle. The findings indicated a lack of awareness among the masses especially women regarding the transfer of inheritance property which occurs in the public sphere. The results are consistent with the previous and current studies conducted in Pakistan (Bibi \& Bangash, 2018; Rubab, Parveen, and Usman, 2016) that there is a lack of awareness about the laws of inheritance and transfer of property.

"Half of the population do not have any awareness regarding inheritance at all". (Urban Female 2, Exploratory Semi-Structured Interview)

"People in the rural area are less aware of the law of inheritance". (Female Lawyer, Exploratory Semi-Structured Interview)

"Men need to be aware of women's rights as they are the ones who make most of the decisions". (Rural Female 1, Exploratory Semi-Structured Interview)

The participants mentioned that the government should run an awareness campaign to aware people of the legal procedures of the transfer of inheritance property. The findings revealed several strategies to spread awareness on the inheritance rights of women.

"Seminars at the union council level in rural areas should arrange to aware them of their rights". (Urban Male 1 \& Rural Male 3, Exploratory Semi-Structured Interviews)

The findings indicated another strategy to spread awareness about the inheritance rights of women through social media.

"Social media can be used to spread awareness about the inheritance property of women". (Urban Female 1, Urban Male 1\& 3, Female Lawyer 3 \& 4, Exploratory Semi-Structured Interviews)

The findings revealed further about creating awareness in a way that is appealing to the communities and as inheritance right is the religious right of women so the awareness should create through religious means as well.

"Friday sermons can be used to raise awareness about inheritance share as people attend and listen these sermons". (Rural Female 6, Rural Male 1, and Male Lawyer 5, Exploratory SemiStructured Interviews)

Changing Socialization: Measures at the Family Level

The primary role of the family is to socialize the children and the family played its role by nurturing and protecting their future generations. Besides, learning love, intimacy, and care, children also learn inequality, injustice, and exploitation from the family. This gender role discrimination through socialization is very much obvious when it comes to the distribution of material resources particularly inheritance property. This has also been highlighted by Okin, (1989) in her study that family holds power over women and children and responsible for creating inequality through socialization. The findings indicated some of the strategies to alter gender socialization patterns about the inheritance property of women.

"People think that sons are the owner of family property and they only tell their sons about property matters so it is essential to train both boys and girls about property matters". (Rural Female 8, Exploratory Semi-Structured Interview)

"Practice of giving property as a gift to son should be changed and women should not withdraw their share and parents are forced to give their daughters due share". (Rural Female 5, Exploratory Semi-Structured Interview)

"Changing mindset is required by considering daughters as one of the members of the household even after marriage as this can help the women as worthy member in the family". (Rural Female 1, Exploratory Semi-Structured Interview) 
"Fathers can play a role in changing mindset by involving daughters in decision making of their lives". (Urban Male 4, Exploratory Semi-Structured Interview)

The findings further revealed by providing education to the girls is another strategy that can alter power relations within the family along with socialization.

"Women's knowledge about inheritance property can make a difference in getting inheritance property". (Rural Female 2, Exploratory Semi-Structured Interview)

"Schools can play a role in disseminating knowledge about inheritance as children can learn about property rights during this time". (Rural Male 3, Exploratory Semi-Structured Interview)

"Inheritance property rights must be included in the curriculum at all levels of education by the state". (Rural Male 7, Exploratory Semi-Structured Interview)

\section{Personnel Changes: Measures at Individual Level}

The findings indicated the last strategy suggested by participants that changing mindset is the key to build an environment where women can take charge of their own lives rather than keep quiet and wait for their inheritance share. Women should come forward for their rights within their families.

\section{Conclusion}

The research was a way forward to take steps towards the implementation of the existing laws in favor of women to get their inheritance property share. The researchers with participants' resolve suggested a four-tier strategy to alter the current situation of women about their inheritance property align with feminist knowledge production. Changes suggested taking measures at different levels, the state, community, family, and individual women to make alternations in the current situation. Procedural measures suggested at the state level to make specific changes at the public offices and courts by hiring women in these offices and gender sensitivity training of the existing men about dealing with women. As well as recommended to set up monitoring cells at the national and provincial levels to check the record of the court decisions about women given their due share of inheritance property. Measures at the community level, the emphasis was more on spreading awareness through various means like media, social media, Friday sermons, as well as the organization of seminars at union councils about the inheritance property of women. The suggestions at the family level focused on altering the socialization patterns and this is a combination of state decided to make a change in the family headship through legal provision to both men and women as head of the family and changing mindset through awareness at the community level as well as the training of boys and girls on equal footing at home. The individual-level measures focused on women themselves to make decisions of their own lives in all aspects of their life including inheritance property.

\section{References}

Abbott, P. A., Wallace, C. D., \& Tyler, M. (2005). An Introduction to Sociology: Feminist Perspectives (3rd Ed.). Routledge.

Ahmad, N. (2010). Land Rights for Muslim Women: Review of Law and Policy. Accessed online www.sdpi.org/publications/files/Microsoft\%20word\%20\%20policy\%20Brief\%2013.pdf.

Agarwal, B. (1996a). A Field of one's Own: Gender and Land Rights in South Asia. New Delhi: South Asia by Cambridge University Press India Pvt. Ltd. (Reprinted in 2008).

Bibi, F. \& Bangash, K.A. (2018). DENIAL OF WOMEN'S INHERITANCE RIGHTS IN PAKHTUN SOCIETY: A STUDY OF SOCIO-CULTURAL VALUES AND CUSTOMARY PRACTICES. Pakistan Journal of Society, Education, and Language (PJSEL), 4(2), 40-53. Retrieved from https://pjsel.jehanf.com/index.php/journal/article/view/97

Black's Law Dictionary. (1999). $7^{\text {th }}$ ed., edited by Brayan A. Garner. West Group.

Blumberg, R. L. (2004). Women's Rights, Land Rights, and Human Rights: Dilemmas in East Africa. Journal of Development Alternatives and Area Studies, 23(3-4), 17-32.

Bran, V. \& Clarke, V. (2006). Using Thematic Analysis in Psychology. Qualitative Research in Psychology, 3(2). 77-101. Taylor \& Francis Group.

Deininger, K., Goyal, A., \& Nagarajan, H. (2013). Women's Inheritance Rights and Intergenerational Transmission of Resources in India. Journal of Human Resources, 48(1), 114-141. Retrieved from www.doi.org/10.1353/jhr.2013.0005. Acceded 26 ${ }^{\text {th }}$ April 2017.

Domingo, P. (2013). Property Rights and Development: Property Rights and Social, Political, and Economic Empowerment. Shaping Policy for Development. London: Overseas Development 
Institute. Retrieved from https://www.odi.org/sites/odi.org.uk/files/odiassets/publications ...files/8508.pdf

Duffo, E. (2003), Grandmothers and Granddaughters: Old-Age Pensions and Intra-household Allocation in South Africa. World Bank Economic Review, 17 (1), 1-25.

Food and Agriculture Organization (2016). Gender and Land Rights-Understanding Complexities, Adjusting Policies. Retrieved from www.fao.org/gender/landrights. Accessed on $24^{\text {th }}$ April 2018.

GENDERNET. (2012). Women's Economic Empowerment, The OECD DAC Network on Gender Equality (GENDERNET), Promoting Pro-poor Growth: The Role of Empowerment-OECD 2012. Retrieved from www.oced.org/dac/poverstyreduction/50157530.pdf. Accessed on $4^{\text {th }}$ July 2018.

Government of Pakistan (1908). The Registration Act, 1908 (Amendment in section 78). Retrieved from http://punjablaws.gov.pk/laws/36a.html

Government of Pakistan (1961). The Muslim Family Law Ordinance 1961(VIII 1961) (Amendment in section 4). Retrieved from http://punjablaws.gov.pk/laws/777a.html

Government of Pakistan (1967). The Land Revenue Act, 1967 (Amendments in the procedure for making records in section, 41-A, 41-B, 42). Retrieved from http://punjablaws.gov.pk/ laws/212.html

Government of Pakistan (1967). The Punjab Land Revenue Act, 1967 (Amendment in section 135-A). Retrieved from http://punjablaws.gov.pk/laws/212.html

Government of Pakistan (1968). The Punjab Revenue Rules, 1968 (Amendments in attestation of inheritance mutation). Punjab Land Records Authority. Retrieved from https://www.punjabzameen.gov.pk/LawsAndRules/Processes

Government of Pakistan (2011). Prevention of Anti-Women Practices Act, 2011(Amendment in 498-A of Pakistan Panel Code). Retrieved from https://pcsw.punjab.gov.pk/prevention_of_anti_ women_practices

Government of Pakistan (2012). The Punjab Partitioning of Immovable Act, 2012 (Act IV of 2013). Retrieved from http://punjablaws.gov.pk/laws/2528.html

Government of Pakistan. The Stamp Act, 1899 (Amendment in section 9 (a)). Retrieved from http://punjablaws.gov.pk/laws/15.html

Government of Pakistan. The Transfer of Property Act, 1882 (Amendment in Sub-section 6 (1)). Retrieved from http://punjablaws.gov.pk/laws/8c.html

Government of Punjab (2009). Benefits of family pension (para 8 (2) (a)). Finance Department, O. M. Retrieved from http://www.finance.gov.pk/circulars/circular_07072015_family_pension.pdf

Grabe, S., Dutt, A., \& Dworkin, S. L. (2014). Women's community mobilization and well-being: Local resistance to gendered social inequities in Nicaragua and Tanzania. Journal of Community Psychology, 42(4), 379-397.

Guba, E. G., \& Lincoln, Y. S. (1994). Competing paradigms in qualitative research. In N. K. Denzin \& Y. S. Lincoln (Eds.), Handbook of qualitative research, 105-117. Thousand Oaks, CA: Sage.

Hanisch, C. (1969). The personal is Political. Introduction by Carole Hanisch, 2006.

Harari, M. (2014). Women's Inheritance Rights and Bargaining Power: Evidence from Kenya. Kenya: Massachus Institute of Technology

Harding, S. (1987). Introduction: Is There a Feminist Method? In Sandra Harding (Eds.), Feminism and Methodology: Social Science Issues (1-14). Milton Keynes: Open University Press.

Holden, L. \& Chaudhary, A. (2013) Daughters' inheritance, legal pluralism, and governance in Pakistan, The Journal of Legal Pluralism and Unofficial Law, 45:1, 104-123, DOI: 10.1080/ 07329113.2013.781447

Human Rights Commission of Pakistan (2008). The State of Human Rights in Pakistan 2007. Lahore: Human Rights Commission of Pakistan.

Judoon, M.A., and Khan, R. (2015). A Survey of Practices and Methods of Denial of Inheritance to Females in Khyber Pakhtunkhwa, Pakistan. Pakistan Journal of Criminology, 7(4), 112-126.

Kelker, G. \& Maithreyi, K. (2013). Women, Land \& Power in Asia. New Delhi: Routledge.

Kenney, N., and Ana, P. (2016). Developing Gender-Equitable Legal Frameworks for Land Tenure: A Legal Assessment Tool. Rome: Food and Agriculture Organization of the United Nations. 
Luke, N. and K. Munshi (2011), Women as Agents of Change: Female Income and Mobility in India. Journal of Development Economics, 94 (1), 1-17.

National Commission on the Status of Women (NCSW) (2008). Women's Rights of Inherence and its Implementation. Islamabad: Government of Pakistan.

Okin, M. S. (1989b). Justice, Gender, and the Family. United State of America: Basic Books.

Qian, N. (2008). Missing Women and the Price of Tea in China: The Effect of Sex-Specific Earnings on Sex Imbalance. The Quarterly Journal of Economics, 123(3), 1251-1285. Retrieved from https://doi.org/10.1162/qjec.2008.123.3.1251pdf. Accessed on $17^{\text {th }}$ July 2018.

Quisumbing, A. R. \& Otsuka, K. (2001). Land Inheritance and Schooling in Matrilineal Societies: Evidence from Sumatra. International Food Policy Research Institute: Washington. Retrieved from www.ageconsearch.umn.edu/bitstream/50054/2/capriwp14.pdf. Accessed on $18^{\text {th }}$ May 2017.

Rao, N. (2005a). Women's Rights to Land and Assets Experience of Mainstreaming Gender in Development Projects. Economic and Political Weekly, 40(44/45), 4701-4708.

Rehman, U. S. (2010). Denial of women's Rights of Inheritance: Enhancing their Vulnerability to Domestic \& Social Violence. Awaz Foundation Pakistan: Centre for Development Services Multan, Pakistan.

Rubab, I., Parveen, S. \& Usman, A. (2016). Islamic Law of Inheritance: Awareness among Women of Punjab. Al-Qalam. 21, 11-23.

Sustainable Development Policy Institute (SDPI) (2008). Land rights for Muslim women: Law and Policy Review. Islamabad: Sustainable Development Policy Institute.

Shafqat, A., \& Zahir, H. (2016). Evaluating 2015 Legal Reforms Related to Land Inheritance and their Impact on Women. Lahore: Punjab Commission on the Status of Women.

Stanley, L., and Wise, S. (1993). Breaking Out Again. London: Routledge.

Strickland, R. (2004). To Have and to Hold Women's Property and Inheritance Rights in the Context of HIV/AIDS in Sub-Saharan Africa. International Center for Research on Women and collaboration with the Global Coalition on Women and AIDS.

Thorne, B. (1987). Re-Visioning Women and Social Change: Where are the Children? Gender and Society, 1(1), 85-109. Retrieved December 3, 2020, from http://www.jstor.org/stable/190088

UN Economic and Social Commission for Asia and the Pacific (UNESCAP) (2013). Review of the Progress and remaining challenges in the implementation of the Beijing Platform for Action in Asia and the Pacific. Asian and Pacific Conference on Gender Equality and Women's empowering: Beijing +20 review. Bangkok

UNDP. (2015). Human Development Report 2015: Work for Human Development. New York: United Nations for Development Program.

USAID. (2013). Land Rights are Fundamental to Millennium Development Goals. Retrieved from www.usaidlandtenure.net/.../land-rights-are-fundamental-to-millennium-development. Accessed on $12^{\text {th }}$ May 2018.

Zaman, S. (2014). Forced Marriages and Inheritance Deprivation in Pakistan: A Research Study Exploring Substantive and Structural Gaps in the Implementation of Prevention of AntiWomen Practices [Criminal Law Amendment Act], 2011 in Six Select Districts of Pakistan. Lahore: Aurat Publication and Information Service Foundation. 